\title{
Optimization of stocking rates of tiger shrimp under modified improved culture system
}

\author{
M.L. Islam and M.J. Alam \\ Bangladesh Fisheries Research Institute, Brackishwater Station, Paikgacha, Khulna- 9280, Bangladesh
}

\begin{abstract}
With the target of increasing the shrimp (Penaeus monodon) production through farm development and improved grow out management, an experiment was conducted with three different stocking densities viz. $5 / \mathrm{m}^{2}$ (T1), $7 / \mathrm{m}^{2}$ (T2) and $9 / \mathrm{m}^{2}$ (T3). Results of the experiment revealed that, among the water quality parameters, values of dissolved oxygen and transparency were lower in the higher stocking densities with significant difference $(p<0.05)$ among the treatments. Other water quality parameters were similar in all the treatments. Bacterial load in bottom sediment had the trend to increase with increasing culture period and showed significant difference $(p<0.05)$ among the treatments with the highest in the higher stocking density. Soil pH in the end sample reduced a little bit in all the treatments than the initial. Deposition of organic matter, phosphorus and nitrogen was related to the respective stocking densities. Final weight gain and survival rate of shrimp were significantly $(p<0.05)$ higher in T1 than in T2 and T3. Stocking density of $5 / \mathrm{m}^{2}$ showed the highest production of $759.14 \pm 19.002 \mathrm{~kg} / \mathrm{ha}$, which was significantly $(P<0.05)$ higher than that of $670.77 \pm 16.078 \mathrm{~kg} / \mathrm{ha}$ obtained in $\mathrm{T} 2$, but similar to $701.24 \pm 33.507 \mathrm{~kg} / \mathrm{ha}$ obtained in T3. The net economic return and BCR was also significantly higher $(p<0.05)$ in the same stocking density $\left(5 / \mathrm{m}^{2}\right)$ compared to others. Whereas, FCR value was significantly lower $(p<0.05)$ in T1 than the other two treatments. However, pond ecological conditions were more congenial for shrimp culture in lower stocking density $\left(5 / \mathrm{m}^{2}\right)$, which minimized the risk of disease outbreak in the respective stocking density, keeping the culture environment favorable.
\end{abstract}

Key words: Stocking density, Tiger shrimp, Modified improved culture

\section{Introduction}

Most of the traditional shrimp farmers in Bangladesh only stock shrimp post-larvae indiscriminately and selectively harvest the adult shrimp, with minimum recovery rate and production (Roy et al., 1997). Optimum stocking density in aquaculture is the triggering factor for maximizing the survival rate and production. Stocking density of shrimp mainly depends on the condition of the culture tank and management practice followed. Optimum stocking density of shrimp plays a vital role minimizing the environmental risk and maximizing per unit production. There have available information regarding the high tech shrimp culture system like semi-intensive to intensive in the world (semi-intensive ponds in Mexico by GuererroGalvin et al., 1998-1999; intensive ponds in Thailand by Briggs and Funge-Smith 1994, 1998; intensive ponds in Australia by Burford et al., 2003a; intensive tanks in Brazil by Thompson et al., 2002). But, the information obtained from these studies on culture system of shrimp never reflects the situation of the coastal farms in Bangladesh. The infrastructural facilities of the coastal areas, the land pattern and ability of the resource poor marginal farmers never permitted to adopt such high tech practice of shrimp farming over the farming areas. Few literatures on the monitoring of water quality and nutrient dynamics of extensive shrimp farms are also available (Alongi et al 2000; Wahab, et al, 2001 and 2003; Islam, et al, 2004). But information regarding a moderate stocking density of shrimp with synchronized culture technique, which might be environment friendly, economically viable and socially acceptable is scarce to nil. The information presented in this paper reflected a moderate stocking density of shrimp under modified improved culture system for promoting per unit production than the existing level in the South-west coastal areas in Bangladesh. 


\section{Materials and Methods}

To optimize the stocking density of shrimp under modified improved culture system and to have its effect on the culture environment; trial was conducted in earthen ponds (each $0.2 \mathrm{ha}$ ) of the Brackishwater Station of Bangladesh Fisheries Research Institute. The experiment was conducted with three different stocking densities viz. $5 / \mathrm{m}^{2}$ (T1), $7 / \mathrm{m}^{2}$ (T2) and $9 / \mathrm{m}^{2}$ (T3) each with three replications. Data were analyzed using Completely Randomized Design (CRD) protocol.

About $200 \mathrm{~m}^{2}(10 \%)$ area of each pond was enclosed with nylon net fastened with bamboo frame for in-pond nursery of shrimp post larvae (PL). Bamboo sticks were provided within the nursery enclosure at a density of $3-4 / \mathrm{m}^{2}$ as shelter for the PL and also for the development of periphytonic films as initial feed for shrimp PL. The ponds under the trial were prepared through drying and liming the bottom-soil with agricultural lime @250 kg/ha. The ponds were fed with tidal water up to a depth of $65-75 \mathrm{~cm}$ and the water was treated with $20 \mathrm{ppm}$ bleaching powder. Then the ponds were fertilized with urea @2.0-2.5 ppm, TSP @ 3.0-3.5 ppm, MP @0.6-0.8 ppm and then left over for 7 days for the growth of available primary producer.

After 7 days of fertilization, the post larvae (ABW, $0.007 \mathrm{~g}$ ) of $P$. monodon were stocked in each in-pond nursery enclosure according to the design. Shrimps in all ponds were fed with commercial nursery feed @ 100\%,60\%, and 30\% of the estimated shrimp biomass for the $1^{\text {st }}, 2^{\text {nd }}$, and $3^{\text {rd }}$ week, respectively. After 14 days of rearing within the in-pond nursery enclosure the juveniles were allowed to spread over the culture pond by up folding the nets. Afterwards, grow out pellet feed was supplied @ 3-5\% of the estimated shrimp biomass twice a day for the rest of the culture period. Like that of the traditional ghers, there was no practice of regular water exchange in each lunar cycle, except occasional addition to replenish any loss due to evaporation or seepage. As post stocking management, all ponds were limed @ 10-12 ppm with an equal mixture of $\mathrm{CaCO}_{3}$ and $\mathrm{CaMg}\left(\mathrm{CO}_{3}\right)_{2}$, fortnightly during the entire culture period. Additional liming was also done at the same rate after every heavy rainfall. The ponds were fertilized with urea, TSP and MP @ 0.5-0.8 ppm, 1.0-1.20 ppm and 0.3-0.4 ppm, respectively at fortnight interval up to 60 days of culture.

During the entire culture period, pond ecological parameters like, temperature, transparency, water depth, $\mathrm{pH}$, Dissolved oxygen and salinity were monitored bi-weekly intervals. Bacteriological load (Total Heterotrophic Colony Forming Unit) in bottom sediment was monitored on initial, mid and at the end of the culture cycle. Whereas, bottom sediment sample was collected at initial and end of the culture cycle, processed and analyzed. Analysis of water quality, bacterial load and soil sample was done following the methods of (APHA, 1992).

After 90 days of rearing, a jumping growth of some shrimp in each pond was observed. At that time selective harvesting was started using cast net and shrimp trap. The harvesting was continued and ended at 120 days by dewatering the ponds. Then growth, survival rate, FCR and production were estimated. Economic analysis was done considering all variable costs to the expenditure and respective shrimp sales of the treatment to the gross return. ANOVA was done to observe the differences in growth, survival rate, production, FCR values and economic return among different treatments. But in case of bacterial load and observed soil characteristics ANOVA was carried out between different sampling periods.

\section{Results and Discussion}

Results on water quality parameters during the entire culture period have been presented in Table 1. However, pH of water in all the ponds lies between 7.7 and 8.4, which was alkaline in condition. Alkaline water is more suitable for aquaculture rather than neutral or acidic. 
Acidic water restricted the growth of primary producer and also reduced feeding affinity of aquatic organisms (Boyd, 1989). Variation in $\mathrm{pH}$ in the present trial was within an optimum range (7.7-8.4) and congenial for shrimp culture for the entire period avoiding any unionized $\mathrm{NH}_{3}-\mathrm{N}$ toxicity for prawn (New, 1995). Water temperature was almost similar in all the treatments and the highest level $\left(39.60{ }^{\circ} \mathrm{C}\right)$ was found during prolonged draught after 55 days of culture in June (Fig. 1). At that time, dissolved oxygen (DO) decreased in all the treatments (Fig. 2) and dropped to its minimum level of $4.0 \mathrm{mg} / \mathrm{l}$.

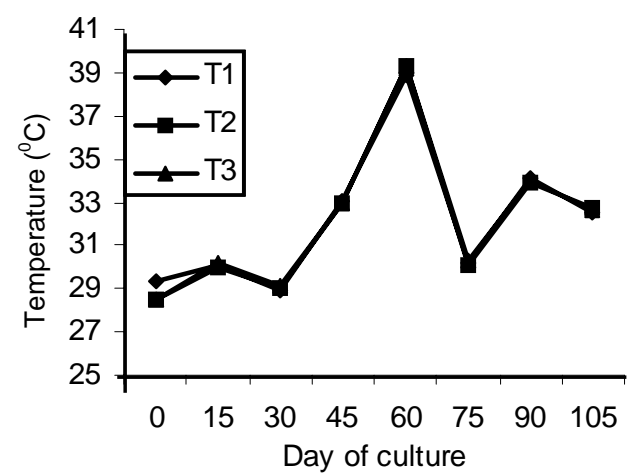

Fig. 1. Temperature regime during the culture period under different stocking densities

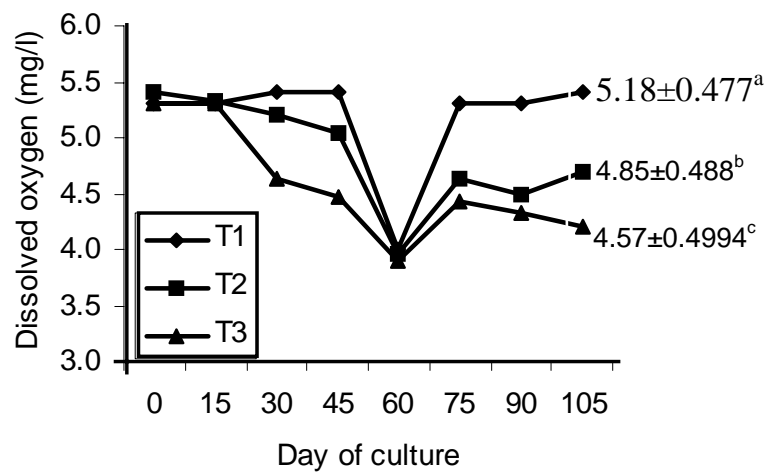

Fig. 2. Trend in dissolved oxygen during the culture period under different stocking densities

Dissolved oxygen in aquaculture inversely related to temperature (Boyd, 1989). Dissolved oxygen in aquatic environment might be decreased due to restrictions in photosynthesis during long term cloudy weather by crushing of primary producers. It might also be decreased for decay and subsequent mineralization of organic matter by bacterial activity on the aquatic ecosystem at higher temperature (Schroeder, 1974). So, the lower level in dissolved oxygen in the present trial might be due to utilization of considerable amount of DO for stabilization of uneaten feed, molted shell and excreta by bacterial activity in the sediment-water interface. However, the DO values remained above sub-optimal levels ( $>4 \mathrm{mg} / \mathrm{l}$ ), avoiding environmental stress for shrimp (Chanratchakool et al, 1995). Initially the transparency of water was similar in all the treatments and was congenial $(25-35 \mathrm{~cm})$ for aqua-farming (Boyd, 1989), but it subsequently decreased in all the treatments with the progress of culture period (Fig. 3).

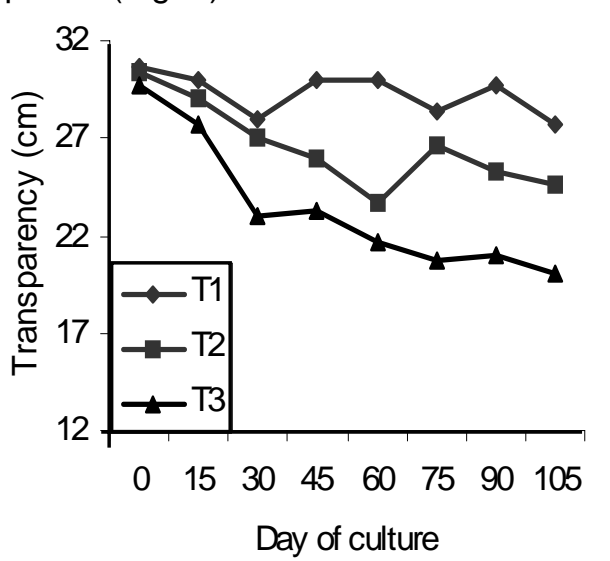

Fig. 3. Status in water transparency under different stocking densities

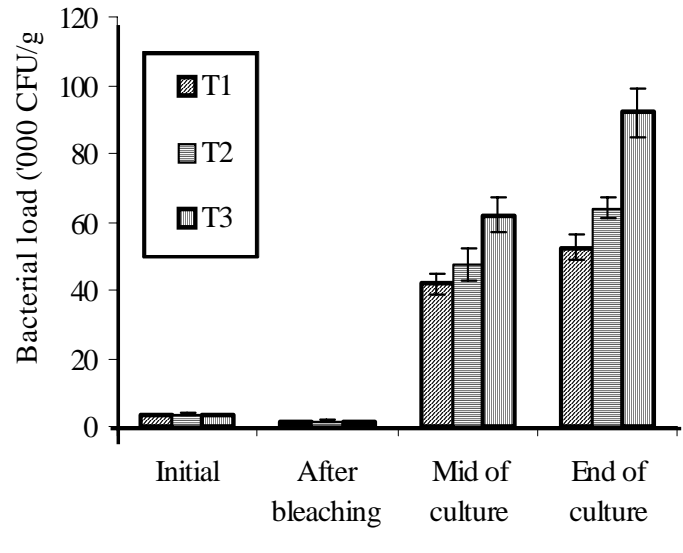

Sampling period

Fig. 4. Status and dynamics in sediment bacteria under different stocking densities 
Transparency showed significant difference among the treatments with the preferable level in lower stocking density. Higher stocking density may lead higher influx of organic matter onto the bottom sediment (Paez-Osuna et al, 1997). Bacterial activity on organic matter released available primary nutrient in water, which is preferable source of nutrient to the primary producer (Saha, 2000) that stimulated the growth of primary producer in the respective ponds might cause lowered transparency level in the respective treatments.

As shown in Fig. 4, bacterial load in bottom sediment was found low at initial sample and decreased to almost zero after application of bleaching, but increased further with the increase in culture duration. The concentration of bacterial load was higher in the end sample and it was highest in higher stocking density at the end of culture period. However, intensification of stocking density of shrimp might lead excessive influx of uneaten feed, faeces and molted shell on to the bottom sediment, which may have increased the bacterial load and activity onto the sediment-water interface. The observation of the present trial was strongly supported by the observation of Saha (2000). Similar bacterial dynamics was also reported by Burford, et al, (2003b) under zero exchanged and highly intensified shrimp ponds. Besides, other water quality parameters were congenial for shrimp culture in all the ponds (Table 1) and the differences of other water quality among the different treatments were insignificant.

Table 1. Ranges in water quality parameters of the ponds under different stocking densities

\begin{tabular}{|l|c|c|c|}
\hline \multirow{2}{*}{ Parameters } & \multicolumn{3}{|c|}{ Treatments } \\
\cline { 2 - 4 } & T1 & T2 & T3 \\
\hline Depth (cm) & $63.0-93.5$ & $65.0-95.8$ & $65.0-100.0$ \\
\hline Salinity (ppt) & $8.5-11.0$ & $8.5-11.0$ & $8.5-11.0$ \\
\hline $\mathrm{pH}$ & $7.8-8.4$ & $7.7-8.1$ & $7.8-8.2$ \\
\hline
\end{tabular}

Soil profile indicated that initially the soil was moderate in $\mathrm{pH}$, but $\mathrm{pH}$ level in the end sample reduced in all the treatments than the initial. The reduction of soil $\mathrm{pH}$ between initial and end sample was significant $(p<0.05)$ in T2 and T3 (Fig. 5).

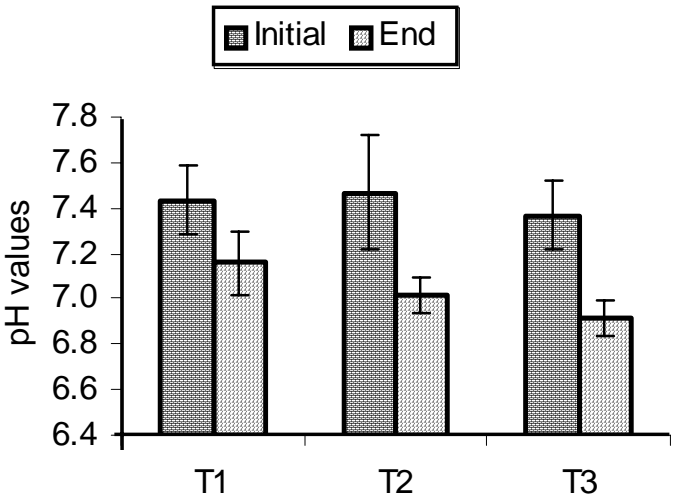

Fig. 5. Status in soil pH under different treatments and samplings

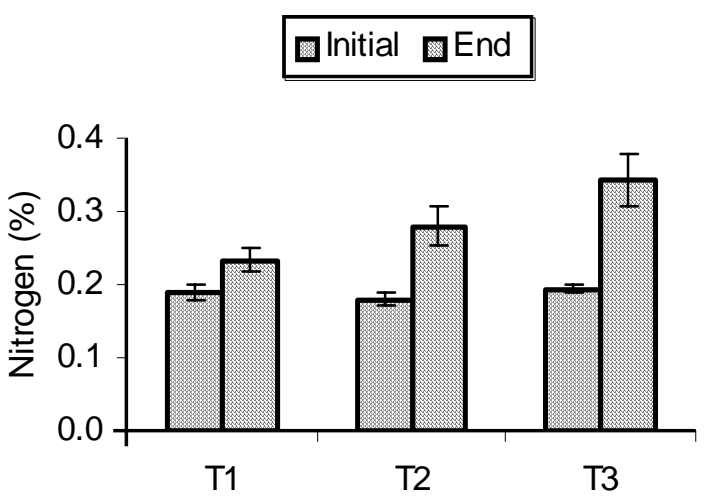

Fig. 6. Status in nitrogen under different treatments and samplings 
The presence of nutrient (Nitrogen and phosphorus) and organic matter in soil was very low in the initial sample, but increased significantly $(p<0.05)$ with culture duration and with the increment of stocking densities (Fig. 6-8). Whereas, in their studies on rotational rice-shrimp farming by traditional method in the same agro-ecological zone, Wahab et al, (2001) and Chakraborti et al, (1985) reported that the percentage of organic matter did not increase significantly and the different parameters monitored did not show extreme value. The findings of present study on soil profile differ with the observation of above mentioned authors.

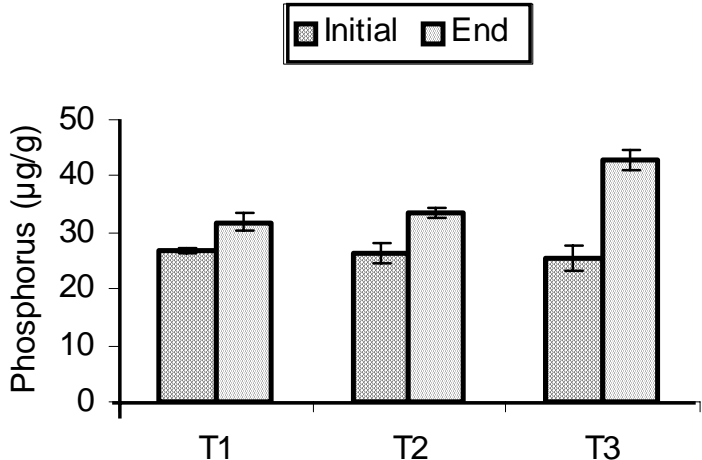

Fig. 7. Dynamics in sediment phosphorus under different treatments

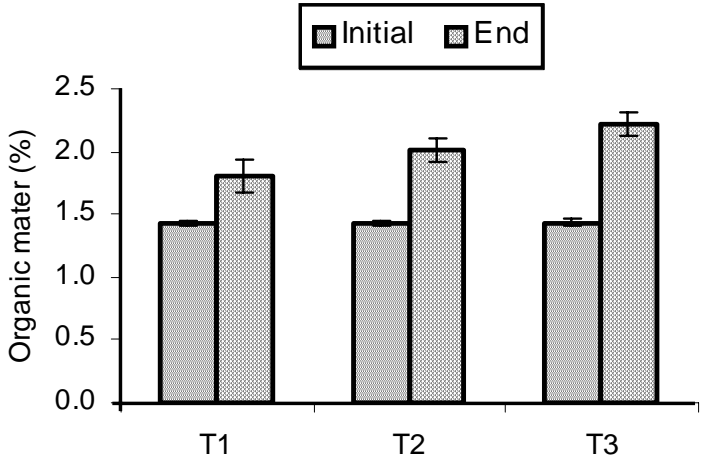

Fig. 8. Dynamics in soil organic matter under different treatments

Optimum stocking density played a vital role in providing better environmental condition. Stocking density of shrimp could be increased to intensive level by increasing the management practices. But such type of stocking densities enhances the accumulation of huge amount of nutrient enriched organic matter into the bottom (Paez-Osuna et al, 1997; Briggs and Funge-Smith, 1994; Briggs and Funge-Smith, 1998; Smith, 1996), which needs to be reduced or excavated after every culture cycle. Hence, the observation of the present trial on soil profile coincided with the observation of above mentioned authors. However, in this experiment though an increased accumulation of nutrient on the bottom sediment was found, but the amount did not exceed the extreme level for aquaculture (Adhikari, 2003) for a single culture cycle of shrimp.

As shown in Table 2, after 120 days of rearing, average weight gain $(26.33 \pm 1.697 \mathrm{~g})$ of shrimp was significantly $(p<0.05)$ higher in T1 than in T2 $(21.33 \pm 0.789 \mathrm{~g})$ and T3 $(20.34 \pm 0.846 \mathrm{~g})$. The survival rate of $57.76 \pm 2.451 \%$ with the lowest stocking density $\left(5 / \mathrm{m}^{2}\right)$ was significantly higher $(\mathrm{p}<0.05)$ than that of T2 $(44.98 \pm 2.075 \%)$ and T3 $(38.32 \pm 1.385 \%)$. Stocking density of $5 / \mathrm{m}^{2}$ performed the highest production of $759.14 \pm 19.002 \mathrm{~kg} / \mathrm{ha}$, which was significantly $(P<0.05)$ higher than that of $670.77 \pm 16.078 \mathrm{~kg} / \mathrm{ha}$ obtained in $\mathrm{T} 2$, but similar to $701.24 \pm 33.507 \mathrm{~kg} / \mathrm{ha}$ obtained in T3. However, production of shrimp between T2 and T3 was insignificant $(p>0.05)$, indicated higher production in lower stocking densities. The FCR value $(2.15 \pm 0.082)$ was significantly lower $(p<0.05)$ in $T 1$ than the other two treatments. 
Table 2. Details of production performance and economic analysis of shrimp (Penaeus monodon) under different stocking densities

\begin{tabular}{|l|c|c|c|}
\hline \multirow{2}{*}{ Particulars } & \multicolumn{3}{|c|}{ Treatments } \\
\cline { 2 - 4 } & $\mathrm{T} 1$ & $\mathrm{~T} 2$ & $\mathrm{~T}$ \\
\hline Final weight (g) & $26.33 \pm 1.697^{\mathrm{a}}$ & $21.33 \pm 0.789^{\mathrm{b}}$ & $20.34 \pm 0.846^{\mathrm{cb}}$ \\
\hline Survival rate (\%) & $57.76 \pm 2.451^{\mathrm{a}}$ & $44.98 \pm 2.075^{\mathrm{b}}$ & $38.32 \pm 1.385^{\mathrm{c}}$ \\
\hline Production (kg/ha) & $759.14 \pm 19.002^{\mathrm{a}}$ & $670.77 \pm 16.078^{\mathrm{cb}}$ & $701.24 \pm 33.507^{\mathrm{ba}}$ \\
\hline FCR & $2.15 \pm 0.082^{\mathrm{c}}$ & $2.4 \pm 0.075^{\mathrm{a}}$ & $2.35 \pm 0.026^{\mathrm{ba}}$ \\
\hline Variable cost ('000 Tk/ha) & $151.09 \pm 0.695^{\mathrm{c}}$ & $160.57 \pm 1.689^{\mathrm{b}}$ & $171.40 \pm 2.318^{\mathrm{a}}$ \\
\hline Gross return ('000 Tk/ha) & $303.66 \pm 7.601^{\mathrm{a}}$ & $251.54 \pm 6.03^{\mathrm{b}}$ & $245.43 \pm 11.73^{\mathrm{c}}$ \\
\hline Net return ('000 Tk/ha) & $152.56 \pm 8.077^{\mathrm{a}}$ & $90.96 \pm 4.95^{\mathrm{b}}$ & $74.04 \pm 9.41^{\mathrm{c}}$ \\
\hline BCR & $2.01 \pm 0.057^{\mathrm{a}}$ & $1.57 \pm 0.03^{\mathrm{b}}$ & $1.43 \pm 0.0^{\mathrm{c}}$ \\
\hline
\end{tabular}

*Figures with different superscript in the same row differs significantly

Stocking density of shrimp mainly depends on the condition of the culture tank and management practice followed. Shofiquzzoha and Ahmed (2001) found a stocking density of 1-2 under extensive traditional culture system in multiple stocking and harvesting, which provided the production of $156-228 \mathrm{~kg} / \mathrm{ha}$. Shofiquzzoha et al, (2001) suggested a stocking density of $1.0-1.5 / \mathrm{m}^{2}$ for shrimp in shrimp-mullet polyculture. Average production of shrimp obtained in the present experiment was much higher than that of Apud et al, (1984), who reported an average yield of $340 \mathrm{~kg} / \mathrm{ha} / 125$ days of crop at stocking rate of $4-5 / \mathrm{m}^{2}$ in monoculture with supplemental feed and improved water management. While reporting on the dynamics and diversity of extensive to improved extensive shrimp farming, Nuruzzaman et al, (2001) attributed an yield range of $74-221 \mathrm{~kg} / \mathrm{ha}$, Islam et al, (2005) also reported a similar average production of $83-204 \mathrm{~kg} / \mathrm{ha}$ with a density of $2-3 / \mathrm{m}^{2}$, following partial stocking and harvesting pattern for an extended culture period of about 180 - 200 days. However, the average production of shrimp obtained in the present study in a culture period of 120 days seemed to be approximately 3-4 folds higher than those reported by the above mentioned authors for the shrimp farms located in the same agro-ecological region.

The net economic return of Tk.152.56 thousand/ha in T1 was significantly higher $(p<0.05)$ than in T2 (Tk. 90.96 thousand/ha) and T3 (Tk. 74.04 thousand/ha). The BCR was also significantly higher $(p<0.05)$ in the same stocking density than the others. The reasons behind this might be the additional price for seed and feed for the higher stocking densities. It also might be due to the higher market price of shrimp harvested from the lower stocking density. Market price of shrimp generally depends on the quality of product, size of shrimp and international demand. In lower stocking density $\left(5 / \mathrm{m}^{2}\right)$ shrimp attained an average body weight of $26.33 \pm 1.697 \mathrm{~g}$ within the experimental period of 120 days, which provided better market price than the shrimp harvested from the higher stocking densities.

However, the over all finding of the present trial focused that, among the tested stocking densities higher density $\left(9 / \mathrm{m}^{2}\right)$ caused lower growth increment of shrimp and more time needed to reach marketable size. This caused more investment of input, increased the chance of environment degradation leading to disease outbreak. Whereas, lower stocking density $\left(5 / \mathrm{m}^{2}\right)$ provided the highest production and economic output, but provided lowest stress to the culture environment than the others. Considering the culture practice, infrastructural facilities and environmental condition of the farms of the South-west Bangladesh, it could be concluded that stocking density of $5 / \mathrm{m}^{2}$ might be considered as optimum with relevant culture practice to boost up the production few folds than the existing level, minimizing environmental stress and production risk. 


\section{Acknowledgement}

The authors would like to express their sincere gratitude to the Authority of Bangladesh Fisheries Research Institute for allowing to conducting the research. The BARC is also greatly acknowledged for supplementary funding for smooth finishing of the research work.

\section{References}

Adhikari, S. 2003. Fertilization, soil and water quality management in small scale ponds: fertilization requirement and soil properties. Aquaculture Asia, 8(4): 6-8.

Alongi, D.M., Johnson, D.J. and Xuan, T.T. 2000. Carbon and nitrogen budgets in shrimp ponds of extensive mixed shrimp-mangrove forestry farms in the Mekong delta, Vietnam. Aquacult. Res., 31:387-399.

APHA (American Public Health Association). 1992. Standard Methods for The Examination of Water and Wastewater. 18th ed., APHA, Washington, D.C., p. 1266.

Apud, F.D., Gonzales, K. and Deatras, N. 1984. Survival, growth and production of Penaeus monodon fabricus at different stocking densities in earthen ponds with flow-through systems and supplemental feeding. Fish. Res. J. Philippines, 6(2): 1-9.

Boyd, C.E. 1989. Water quality management and Aeration in Shrimp Farming. Fisheries and Allied Aquaculture Development Series No. 2, Alabama Agricultural Experiment Station, Auburn University, Alabana, 83 pp.

Briggs, M.R.P. and Funge-Smith S.J. 1994. A nutrient budget of some intensive marine shrimp ponds in Thailand. Aquacult. Fish. Manage., 25: 789-811.

Briggs, M.R.P. and Funge-Smith, S.J. 1998. Nutrient budgets in intensive shrimp ponds: implications for sustainability. Aquaculture, 164: 117-133.

Burford, M.A., Thompson, P.J., McIntosh, R.P., Bauman, R.H. and Pearson, D.C. 2003b. Nutrient and microbial dynamics in high-intensity, zero-exchange shrimp ponds in Belize. Aquaculture, 219: 393-411.

Burford, M.A., Costanzo, S.D., Dennison W.C., Jackson C.J., Jones A.B., McKinnon A.D., Preston N.P. and Trott L.A. 2003a. A synthesis of dominant ecological processes in intensive shrimp ponds and adjacent coastal environments in NE Australia. Mar. Pollut. Bull., 46: 1456-1469.

Chanratchakool, P., Turnbull, J.F. and Limsunean, C. 1995. Health management in shrimp ponds. Aquatic Animal Health Research Institute, Department of Fisheries, Kasetsart University, Bangkok, 91 pp.

Chakraborti, R.K., Ravichandran, P., Halder, D.D, Mandal, S.K. and Sanfui, D. 1985. Some physico-chemical characteristics of Kakdwip brackishwater ponds and their influence on survival, growth and production of Penaeus monodon (Fabricius). Indian J.Fish., 32 (2): 224-235.

Guererro-Galvin S.R., Paez-Osuna, F., Ruiz-Fernandez, A.C. and Espinoza-Angulo, R. 1998-1999. Seasonal variation in the water quality and chlorophyll a of semi-intensive shrimp ponds in a subtropical environment. Hydrobiologia, 391: 33-45.

Islam, M.L., Alam, M.J., Rheman, S., Ahmed, S.U. and Mazid, M.A. 2004. Water quality, nutrient dynamics and sediment profile in shrimp farms of the Sundarbans mangrove forest, Bangladesh. Indian Journal of Marine Sciences, 33(2): 170-176.

Islam M.S, Milstein, A., Wahab, M.A., Kamal, A.H.M. and Dewan, S. 2005. Production and economic return of shrimp aquaculture in coastal ponds of different sizes and with different management regimes. Aquacult. Inter., 13: $489-500$

New, M.B. 1995. Status of fresh water prawn farming: a review. Aquacult. Res., 26:1-54.

Nuruzzaman M., Anwari, B., Shahjahan, M, and Moniruzzaman, M. 2001. The dynamics and diversity of the shrimp farming in Bangladesh. Final Report. Fourth Fisheries Project, Shrimp and Coastal Aquaculture Component, Department of Fisheries, Bangladesh, $63 \mathrm{p}$.

Paez-Osuna, F., Guerreo-Galval, S.R., Ruiz-Fernandez, A.C. and Espinoza-Angulo, R. 1997. Fluxes and mass balances of nutrients in a semi-intensive shrimp farm in North-western Mexico. Mar. Poll. Bull., No. 34 290-297. 
Roy, P.K., Ahmed, S.U. and Shofikuzzoha, A.F.M. 1997. Optimization of stocking density for environmental friendly improved extensive shrimp farming system in South-west part of Bangladesh. Bangladesh J. Fish. Res., 3(2): 137-143.

Saha, S.B. 2000. Oxygen consumption pattern of some common manures used in pond fertilization. Bangladesh J. Agri., 25(1\&2): 97-102.

Schroeder, G.L. 1974. Night time material balance for oxygen in fish ponds receiving organic wastes. Bemidgeh, 27: 65-74.

Shofiquzzoha, A.F.M. and Ahmed, S.U. 2001. Improving soil, water and productivity of gher fishery. Final Report (Contart Research Project, ARMP, IDA Credit No 2815-BD). Bangladesh Fisheries Research Institute, Mymensingh-2201, Bangladesh, 85p.

Shofiquzzoha, A.F.M., Islam, M.L. and Ahmed, S.U. 2001. Optimization of stocking rates of shrimp (P. monodon) with Brackishwater finfish in a polyculture system. Online Journal of Biological Sciences, 1(8): 694-697.

Smith, P.T. 1996. Physical and chemical characteristics of sediments from prawn farms and mangrove habitat on the Clarence river, Australia. Aquaculture, 146: 47-83.

Thompson, F.L., Abreu, P.C. and Wasielesky, W. 2002. Importance of biofilm for water quality and nourishment in intensive shrimp culture. Aquaculture, 203: 263-278.

Wahab, M.A., Bergheim, A. and Braaten, B. 2003. Water quality and partial mass budget in extensive shrimp ponds in Bangladesh. Aquaculture, 218: 413-423.

Wahab, M.A., Bergheim, A., Braaten, B., Islam, M.S. and Rahman, M.M. 2001. Observation on some of the environmental parameters of selected shrimp farms in Khulna, Bangladesh. Bangladesh J. Fish. Res., 5(1): 75-84. 